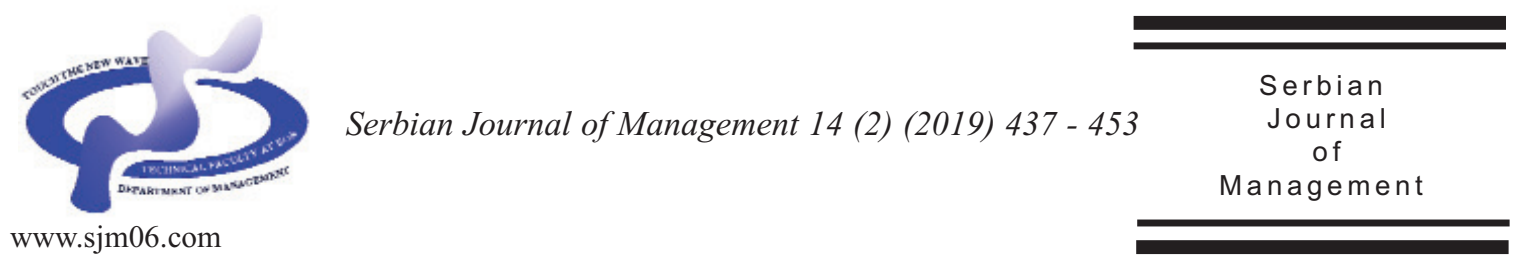

\title{
ANALYSIS OF SUPPORT AND IDENTIFICATION OF BARRIERS TO SMES IN SLOVAKIA AND IN THE CZECH REPUBLIC
}

\author{
Lenka Labudová* and Denisa Jánošová \\ University of Ss. Cyril and Methodius in Trnava, Faculty of MassMedia Communication, \\ Nám. J. Herdu 2, 91701 Trnava, Slovakia
}

(Received 20 September 2019; accepted 01 November 2019)

\begin{abstract}
The aim of the paper is to identify main obstacles in small and medium enterprises and evaluate similar and different features of the state support for entrepreneurship in Slovakia and the Czech Republic, based on detailed analysis and data from questionnaire research. Paper is divided into 5 chapters. In the introduction, authors are trying to focus on purpose of why it is important to support SMEs. The second chapter defines entrepreneurial support and individual support programs for SMEs in the Czech Republic and Slovakia by the European Union and by individual countries. The third chapter focuses on selected questions from research, which was made under the auspices of the project "How to prevent SMEs from failure". It's followed by a discussion and conclusion in which authors point out the biggest obstacles to SMEs that prevent them from successfully remaining on the market.
\end{abstract}

Keywords: entrepreneurship, small and medium enterprises, support tools and programs for SMEs, obstacles for SMEs

\section{INTRODUCTION}

"In the case of ordinary people without any extreme talent, business can be seen as a faster way to make money. An entrepreneur does not have to be an expert in any field. It's best to know a little bit of everything, keep track and don't give up."

(Henry Ford)
Micro, small and medium enterprises (SMEs) play a central role in the economy of a country. They are the driving power of the economy and significantly contribute to the creation of jobs and economic growth, ensuring prosperity and social stability of a country. They have a significant value in the creation of entrepreneurial spirit in a country and in supporting innovations, and thus have

* Corresponding author: labudova123@gmail.com

DOI: $10.5937 /$ sjm14-23494 
a crucial influence on the competitiveness and employment rate of a country. Given their importance for the economy, they are a significant pivot of the EU policy's attention. It is not typical for SMEs to be owned by foreign entities. They represent domestic capital, local ownership, and therefore the business impact, whether positive or negative. The European Initiative - Small Business Act has a specific contribution to SME development and seeks to combat the need for SMEs to be prioritized over the needs of large companies. The goal is to support business and ensure a stable and appropriate business environment for SMEs, in order for these businesses to grow, generate greater value in the overall economy and develop their potential within the global economy. The aim of the paper is to identify main obstacles in small and medium enterprises and evaluate similar and different features of the state support for entrepreneurship in Slovakia and Czech Republic, based on detailed analysis and data from questionnaire research.

\section{SUPPORT SYSTEM FOR AN SME BUSINESS WITHIN THE CONTEXT OF THE EUROPEAN UNION}

The European Union has a complex system of support in various areas, such as regional and urban development, employment and social inclusion, agriculture and rural development, maritime and fishing policy, research and innovations or humanitarian aid. Support pertains mainly to providing financial means, with more than $76 \%$ of the EU budget managed in the form of a partnership with national and regional authorities as part of the so-called shared management (European Commission, 2016).
Incorporation of behavioural economics elements can help to create a more decider friendly decision making environment for those who are faced with difficulties (Moore et al., 2018). These are mainly the 5 European Structural and Investment Funds ("ESIF" from this point on), which help fulfil the Strategies 2020 goals:

- the European Union has a complex system of support in various areas, such as regional and urban development, employment and social inclusion, agriculture and rural development, maritime and fishing policy, research and innovations or humanitarian aid. Support pertains mainly to providing financial means, with more than $76 \%$ of the EU budget managed in the form of a partnership with national and regional authorities as part of the so-called shared management. These are mainly the 5 European Structural and Investment Funds ("ESIF"), which help fulfils the goals of the European Fund of Regional Development (EFRD), which focuses on the strengthening of economic, social and territorial cohesion in the European Union through removing inequality between its regions,

- the European Social Fund (ESF), which focuses on improving the situation of the most vulnerable individuals threatened by poverty, mainly through investments into human sources, with the goal of improving the opportunities in the area of employment and education in the EU,

- the Cohesion Fund (CF), the goal of which is to decrease the economic and social inconsistencies and to support long-term sustainable development, it is therefore focused on those member states whose GDP per inhabitant is lower than $90 \%$ of the EU average;

- the European Agricultural Fund for 
Rural Development (EAFRD), which supports mainly rural areas of the EU (the so-called Rural development program);

- the European Maritime and Fisheries Fund (EMFF), that supports maritime and fisheries policy.

The support for SMEs is, given their key position in the economy, one of the most significant topics in the European Union. It is carried out in various forms and provided directly through grants, loans and guarantees (EIB) or through programs managed at the national and regional level (the aforementioned ESIF). Bartlett and Ghoshal (2003) claimed that companies instead require three kinds of specialists - business managers, country managers, and functional managers - and a set of senior executives to nurture the specialists and coordinate their efforts. SMEs can also utilize many measures of non-financial aid, in the form of programs and services for the support of entrepreneurship (SARIO, 2018). Small and medium enterprises, i.e. businesses under 250 employees and under an annual turnover of 50 mil. EUR, form the decidedly most numerous segment of businesses in Europe, a fact also proven by looking at statistics 99\% of all businesses in Europe are SMEs, with SMEs employing almost $75 \%$ of all people working in the private sector. For this reason, not only Slovakia, but also the EU as a whole has an eminent interest in fostering favourable conditions for their functioning and development.

It is precisely the quality of the business environment that is often considered the main factor of long-term economic competitiveness and long-term sustainable development of small and medium enterprise. Although the auditor is one of the most important external business partners for an SME in terms of knowledge transfer and the mitigation of internal risks, an investigation of the performance drivers of the qualitative change induced by auditing has not taken place to date. According to the OECD, it is possible to divide the factors that influence the business environment into 4 main areas, these being the institutional and regulatory framework, access to markets, access to funds and business culture (FI compass, 2019). Firm failure prediction is playing an increasingly important role in financial decision making (Liu \& Wu, 2017).

Therefore, the European Union, along with the individual member states, is developing several initiatives, including political, legislative and institutional, the main goal of which is the creation of a favourable business environment for SME. Reality reveals enormous variation across social and cultural contexts. For instance, multinational corporations must adjust their management practices to adhere to national regulation and local standards; manufacturers and service providers routinely tailor their products to suit the local preferences of consumers, said Pastuh, (2015).

One of the main initiatives of the European Union in the area of supporting SME is the so-called "Small Business Act“, which, within the framework of the legislative and political process advocates the furthering of several principles for supporting SME, such as the „Think small first" principle, as well as the alleviation of the accessibility of financial sources to the SMEs, and allowing the SMEs to utilise the benefits of freedoms of the single European market to their greatest degree, and also stresses to the European Commission and the individual member states, to take into increased consideration the impacts of approved changes on SME while adopting 
political and legislative decisions (Ježková \& Ježek, 2011).

\subsection{The system of support for small and medium entrepreneurship in Slovakia}

SMEs are the most numerous type of business entities in the Slovak Republic. This group includes business entities that have less than 250 employees, i.e. 249 employees and less. Besides the number of employees, criteria examined during the categorization of business entities include annual turnout and a balance sheet (property in netto evaluation on a balance sheet).

The significance of small and medium businesses in the Slovak economy is characterized by several indicators. In 2016, they continued to represent $99.9 \%$ from the overall number of business entities in the Slovak economy, employing roughly three quarters $(74.1 \%)$ of the active workforce in the business economy and participated in the creation of added value by more than half $(52.7 \%)$.

The current system for supporting SME entrepreneurship in the SR is greatly diversified given the participants involved in this process. The state of financial distress or imminent bankruptcy is very difficult situations that the management of every company wants to avoid (Brozyna et al., 2016). The role of the authorities at the national level is, especially, the development of policies and the acquiring of funds (whether on a national level or on the level of the EU). The goal of agencies, banking institutions and various funds is to carry out policies and also implement the acquired funds in the form of various projects for the support of SME (Eliašová et al., 2017).

Support is provided in the following manner:
Directly as -

- a non-returnable financial donation based on a separate regulation,

- a subsidy,

- financial tool based on a separate regulation.

Indirectly as -

- information and consultancy in the area of entrepreneurship,

- education in the area of entrepreneurship,

- a support remittance related to accepting services in the area of support, based on $\S 2$ Law no. 290/2016 of the Collection of Laws, about the support of small and medium entrepreneurship,

- organizing and supporting participation in research fellowships, competitions, exhibition $\mathrm{s}$ or other events focused on supporting entrepreneurship,

- targeted strengthening of potential of the microbusiness, small business or medium business, which allows to increase its performance,

- long-term specialist consultancy and specialist training, the goal of which is the improvement of business skills and a growth in expertise.

Financial support in the Slovak Republic is carried out mainly through:

- credit,

- microloans,

- venture capital,

- utilization of guarantees,

- through non-returnable financial aid and similar (Hanová, 2017).

Materials related to the support system in Slovakia are developed mainly by the Ministry of Economy of the SR (ME SR), the Slovak Guarantee and Development Bank and the Slovak Business Agency. IrimiaDieguez et al. (2015) claims, that recent years, three new research lines have 
appeared which strive to improve the performance of bankruptcy models and introducing non-financial information as predictor variables.

The legislative framework of entrepreneurship support is the Law no. 290/2016 of the Collection of Laws, about the support of small and medium entrepreneurship, which regulates the activity of the Ministry of Economy of the SR while providing support in the area of small and medium entrepreneurship, defines areas and forms of providing support and simultaneously allows the exercising of European principles in the development of SMEs, confirmed in the agenda of the EU oriented towards the support and development of SMEs, specifically in the socalled Small Business Act.

The Ministry of the Economy of the SR can, within its domain, offer support for:

- the founding of microbusinesses, small businesses and medium businesses,

- the development of existing microbusinesses, small businesses and medium businesses,

- the creation of new jobs or the preservation of existing jobs in microenterprise, small enterprise and medium enterprise,

- the increasing of competitiveness of micro-enterprise, small enterprise and medium enterprise and the strengthening of their position on the internal market of the European Union and outside of the internal market of the European Union,

- projects of associations for the development of microbusinesses, small businesses and medium businesses,

- the preservation and development of traditional industries, crafts, traditional folk crafts and folk artistic products,

- the founding and development of business organizations that create basic wealth on a mandatory basis, with their headquarters in the Slovak Republic, with no more than 36 months having passed since the creation of the business organization, the business organization controlled by physical persons who are its founders, and the business organizations are an innovative business, a micro-enterprise, small enterprise or medium enterprise,

- research and development with the exception of help provided according to separate regulations,

- $\quad$ innovations of products, services and processes,

- the improvement of the business environment (European Commission, 2018).

The Slovak Business Agency, founded by the Ministry of Economy of the SR, Entrepreneurs Association of Slovakia and the Slovak Association of Crafts, provides help for SMEs at a national, regional and local level. It carries out financial as well as non-financial programs for the support of SMEs, as well as projects at a national and European level. Besides the SBA, such programs of mainly state-funded support are also carried out by the Slovak Guarantee and Development Bank and the Slovak Investment and Trade Development Agency.

The SBA carries out a microloan program, the goal of which is to make available new credit funds for microentrepreneurs, small business entrepreneurs and beginner entrepreneurs. Through this program, entrepreneurs can apply for a microloan under favourable conditions. The goal of this program is to allow the development of small businesses, to increase the survival rate of small businesses, by raising the accessibility of credit funds under more favourable conditions. It is possible to use a microloan for the acquisition of 
movable and immovable assets, the reconstruction of operational spaces, as well as the purchase of the necessary supplies or goods. The amount of the microloan varies from 2500 to 50000 EUR and the maturity rate of the credit varies from 6 months to 4 years.

Through the National holding fund s.r.o., a subsidiary company of the SBA, entrepreneurs are also provided with venture capital for supporting growth-oriented business projects. Currently, the NHF administers the following funds:

1. Slovak Development Fund a.s.;

2. Innovations and Technologies Fund;

3. Slovak growth capital fund (Slovak Business Agency, 2017a,b).

\subsection{The system of support for} entrepreneurship in the Czech Republic (CR)

In recent years, Czech SMEs had experienced a slight growth of added value. The added value of small and medium enterprises in the years 2012 - 2016 grew by $9.5 \%$, which is less than in the case of large companies. SME employment in 2016 remained at roughly the same level as in 2012. In the years 2015-2016, the added value increased and the small and medium enterprise employment increased by $3.4 \%$, or by $1 \%$.

It is assumed that the recent growth of the added value of SME will continue, with an expected increase of $8.7 \%$ in the years 20162018. In contrast to that, it is expected that the growth of SME employment will more or less stagnate, achieving only a mild growth by $0.4 \%$ during that same period, which represents roughly 8800 new jobs within the context of SME (Czechinvest, 2018). Company bankruptcy is a frequent research topic, and with regard to current economic developments, its importance and relevance is undisputable, says (Karas \& Reznakova, 2017).

\subsubsection{An overview of the system of support for SME in the Czech Republic}

One of the priorities of the CR's governments is the support for SME, which account for $99.8 \%$ of Czech businesses. Simultaneously, they employ two thirds of the workforce. The principles for providing support while beginning entrepreneurship, as well as the strengthening the economic standing of SMEs, is stated in the CR Law $47 / 2002$ on the support for small and medium enterprise. It defines areas and forms of support, as the following:

1. Returnable financial aid,

2. Subsidy,

3. Financial donation,

4. Guarantees,

5. Credits with a lowered interest rate.

This law created the Investment and Business Development Agency CzechInvest as a state-owned allowance organization of the Ministry of Industry and Trade of the Czech Republic. Besides this agency and the ministry, SME support is also provided by the Czech trade promotion agency CzechTrade and the Design centre CR, as well as the Czech-Moravian guarantee and development bank, a. s. ("CMGDB" from this point on), particularly based on the agreements finalized with the Ministry of Industry and trade of the CR. The CMGDB is the development bank of the CR, which aids in concordance with the intentions of the Czech government's economic policy and the regions of SME development, infrastructure and other sectors of the economy that require public support 
(European social fond in the Czech Republic, 2018).

The strategic document for preparing the program period of EU cohesion policy in the area of entrepreneurship is the Concept of Supporting SMEs 2014 - 2020, approved by resolution no. 923 of the government of the CR from 12. December 2012. The priority of the Concept of Supporting SMEs is focusing support on strengthening the competitiveness of SMEs through the creation and spread of innovations, the development of the business environment, the decreasing of administrative burdens and increasing the quality of consultancy services for SME. An important area of support is the decreasing of energy demands of SME entrepreneurship, especially in relation to utilising reusable resources, with positive impacts for the natural environment. Many companies view late payments as a serious threat to their overall ability to invest in growth and thus employ more staff (Kliestik et al., 2017). Currently, the national programs for the support of SME in the Czech Republic include the programs Guarantee (2015 to 2023), VADIUM (2018 to 2023) and INOSTART (Center for Regional Development of the Czech Republic, 2017).

\section{Guarantee program (2015 to 2023)}

The goal of the Guarantee program is to encourage the access of SMEs to bank credits in order to realize their business projects, through guarantees. Within this program, entrepreneurs are provided with guarantees, individual and portfolio-based, up to $80 \%$ of the principal sum of the guaranteed credit. The size of this credit can be as much as 30 million Czech crowns ("CZK" from this point on). Social enterprises are also provided financial donations up to $10 \%$ of the guaranteed credit, but not more than $500000 \mathrm{CZK}$. Guarantees are issued by the Czech-Moravian guarantee and development bank (CMGDB) for credits provided by the credit-providing banks, mainly for the creation and reconstruction of long-term tangible and intangible assets and the financing of supply chains.

In 2015, the CMGDB took part in the COSME program, a guarantee program utilising the means of the European fund for strategic investments, through which the European Commission wants to encourage investment activity in the EU.

\section{VADIUM program (2018 to 2023)}

The goal of the Vadium program is particularly the support for SME access to orders within the context of selective/assignment processes, through guarantees. Within this program, guarantees are provided to entrepreneurs, which serve as collateral in case of a selective/assignment process declared by an entity headquarter within the territory of the $\mathrm{CR}$, whose subject of focus is the delivery of goods, services or construction work. The guarantee is also issued under the condition that the project is carried out within the territory of the ČR. The entity making the order presents a certificate announcing the tender for the most favourable offer (according to the civic code) or a procurement procedure according to the Law no. 134/2016 of the Collection of Laws., about the issuing of procurement procedures, and a standard request for a guarantee. Guarantees are provided up to $80 \%$ of expenses, with the minimal size of the guarantee being 50 thousand CZK, and the maximum size 5 million $\mathrm{CZK}$. Guarantees are issued by the CMGDB (Center for Regional Development of the 
Czech Republic, 2017). Kliestikova et al. (2017) claim, that bankruptcy shouldn't be considered only as negative phenomena although its impact is for companies in most cases more than devastating. This change of point of view is invoked by the needs of contemporary socio-economic evolution. If society wants to reach sustainable development, the bankruptcy should be perceived as an immanent part of normal cyclical economic development. Moreover, if the view of bankruptcy is changed in a positive way, it can be a stimulus for innovations, investment and global welfare.

\section{INOSTART program}

The goal of the INOSTART program is to allow beginning entrepreneurs to acquire credit for the realisation of innovative projects, and to support the sustainability of the supported innovative projects by a partial covering of the expenses for consultancy, secured by the Česká sporitelna savings bank. It represents a providing of guarantees only to credits from Česká sporitelna, a.s. and the size of the credit can be 0.5 million $\mathrm{CZK}$ at a minimum, and 15 million $\mathrm{CZK}$, at a maximum. The size of the guarantee is provided up to $60 \%$ of the principal sum of the guaranteed credit. The maturity rate is a maximum of 5 years since the date of the first payment of the credit's capital, with a postponement of the credit instalment by a maximum of 3 years. The recipients of aid cover the costs from their own means, cover only part of the credit's value, that is $0.1 \% \mathrm{p}$. a. from the size of the guarantee. Simultaneously with providing the aid recipient with a guarantee, the recipient is provided with a financial donation to cover the costs of the remaining part of the guarantee's value, specifically $1 \%$ p. a. from the value of the guarantee. The aid is meant for beginning entrepreneurs, who have not ran a business for longer than 3 years and work in areas such as the processing industry, energy industry, construction industry, retail and wholesale, information and communication activities and other services (European investment fund, 2016).

\section{HOW TO PREVENT SMES FROM FAILURE - RESEARCH}

The research, under the auspices of the project How to prevent SMEs from failure, was carried out in early 2019 by V4 countries and Serbia. "This project is focusing to assess the factors influencing the failure of other entrepreneurs, and based on that, to develop the measuring scale, that will help existing business to avoid potential failure. Analysis of the factors influencing SMEs failure and the possibility of their enhanced recovery has not been enough investigated in the region of Serbia. Through this project, we will analyse the reasons for SMEs failure in V4 countries, but also the potential for their recovery.", (Visegrad Fund Project 2018, 2019). Specifically, Slovakia, Czech Republic, Hungary, Poland and Serbia. The research was carried out by a questionnaire consisting of 51 questions. The questionnaire was filled in by the owners or management of SMEs that have gone through the crisis. The sample in Slovakia was 121 respondents, in the Czech Republic 95, in Poland, in Serbia 134 and in Hungary 100 respondents.

In this paper we decided to select 7 research questions and compare their results between our country (Slovakia) and the Czech Republic, as we are closest from the economic point of view. 


\subsection{Research hypotheses}

Based on the research questions stated in chapter 4 , the hypotheses to be tested in the course of this research are stated below:

H1. Financial difficulties were the main obstacle to success before the final financial crisis.

The hypothesis is based on the SBA agenda and its results of selected financial indicators point to a more significant impact of changes in the Slovak economy on the SME sector. In 2017, only $56.1 \%$ of SMEs achieved a positive economic result (2017 SBA Fact Sheet Slovakia, 2019).

H2. The company got into crisis in the first years of business (was not older than 3 years).

The hypothesis is based on SBA data from 2016 and 2017, when the largest number of small and medium-sized enterprises (19\%) closed down their businesses, before the company reached the age of 3 years (2017 SBA Fact Sheet Slovakia, 2019).
H3. The most important success factor in business is risk taking.

The hypothesis is based on article from authors Allah \& Nakhaie (2011), they claim that the entrepreneurs wouldn't consider every kind of risk, but they consider rational and certain risks. It means the entrepreneurs, not only follow the ideas as working situations, but also consider the current risks of these ideas.

\section{RESULTS}

\section{Q1 - Your age}

The age structure of 40-49 years was the largest group among respondents from the Czech Republic (Figure 1), it consists 31 respondents, which is 33\%. Group 50-59, $26 \%$ is on the second place and the smallest number of respondents was over 59 years, $12 \%$.

In Slovakia (Figure 2), the age group 5059 was among the respondents, the biggest one - 56 respondents, $46 \%$. The second group represented the age of 40-49 years and the number of respondents $40.33 \%$.

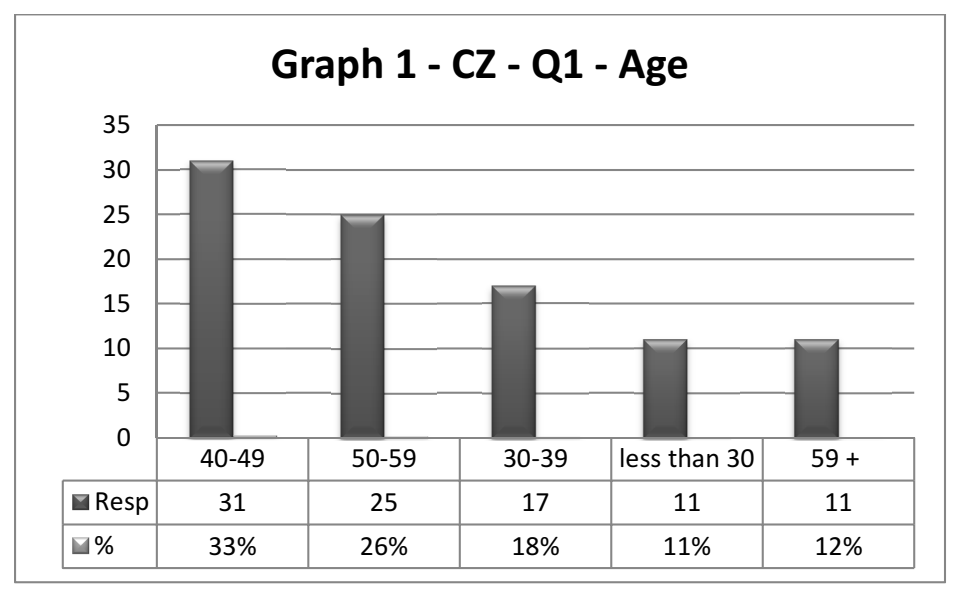

Figure 1. The age structureof respondents from the Czech Republic 


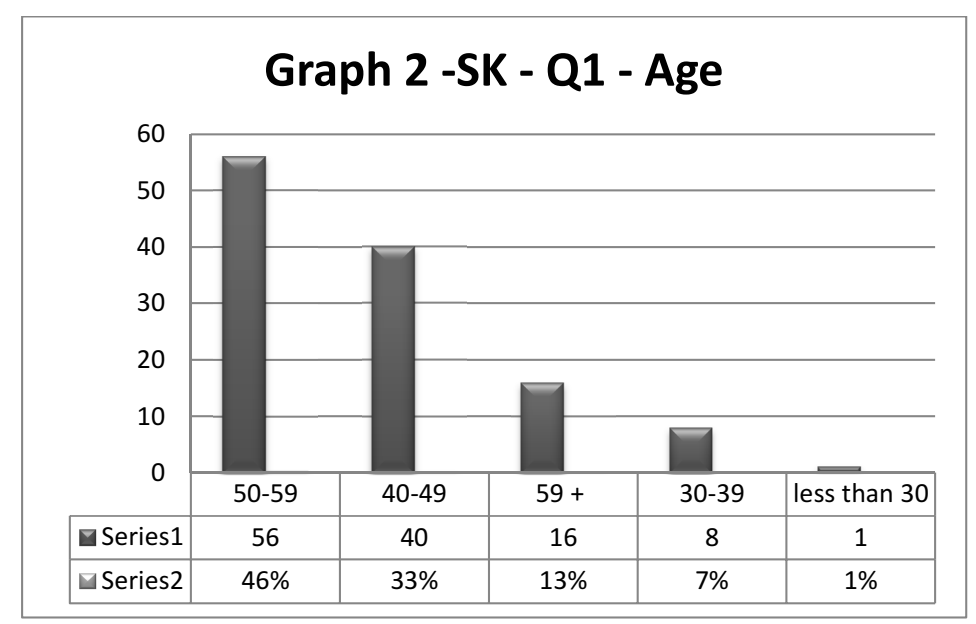

Figure 2. The age structureof respondents from the Slovakia

\section{Q3 - Gender}

Of the total number 95 respondents in the Czech Republic, 63 were men and 32 were women (Figure 3).

Questionnaire in Slovakia was completed by 98 men and 23 women (Figure 4 ).

Q16 - Please indicate the main obstacles to doing business before the financial crisis

Based on the processed results from the Czech Republic (Figure 5), the 5 most common answers to the question of identifying the main obstacles to business success before the financial crisis were- Lack of customer interest (30\%), Competition (29\%), Financial difficulties (14\%), Lack of skilled labor (14\%) and other (13\%).

In Slovakia (Figure 6), respondents stated Competition (40\%), Financial difficulties $(36 \%)$, Lack of customer interest / demand $(8 \%)$, Lack of resources $(7 \%)$ and Lack of skilled labor (4\%) as the main obstacles.

Q18 - Rate the importance of following factors for company's success.
In question number 18 , respondents rated the importance of factors, which lead to business success. They rated them on a scale of 1 (least important) to 5 (the most important). The Table 1 shows the number of respondents in each country's column marked either 4 or 5 for each factor. X means that none of the respondents marked this factor.

In question number 18, respondents rated the importance of factors, which lead to business success. They rated them on a scale of 1 (least important) to 5 (the most important). The table below shows the number of respondents in each country's column marked either 4 or 5 for each factor. $\mathrm{X}$ means that none of the respondents marked this factor.

Q29 - Age of the company in the time of financial distress

In question 29, we asked about the age of the company in times of crisis. Respondents had the opportunity to choose from 3 options - Within 3 years, from 3 to 5 years or more than 5 years. In both cases, the most common answer was the option - More than 5 years (Figure 7,8). 
Q41 - Did you have some help in solving difficulties. 12 respondents answered No. your financial problems?

In question 41, we asked whether respondents asked for help in solving their business difficulties.

In the Czech Republic (Figure 9), 70 respondents answered YES and 25 decided that they did not need any help in solving their financial situation.

In Slovakia (Figure 10), 109 respondents answered positively to the question whether they needed help in solving their financial

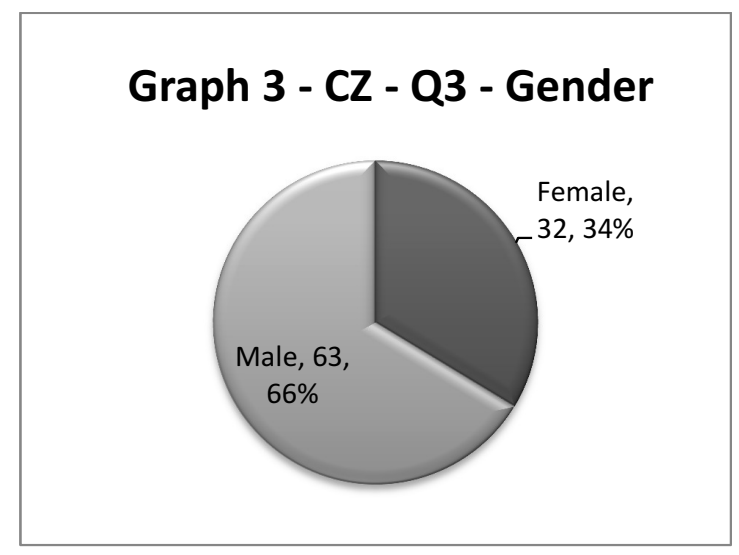

Figure 3. The gender structure of respondents from the Czech Republic
Q42 - Who helped you in solving your financial problems?

Respondents who answered - Yes in question 41 , in this question identified who they were seeking help from.

Czech respondents were looking for help outside their families and their friends, they chose outside adviser.

Slovak respondents decided to seek help from family and friends.

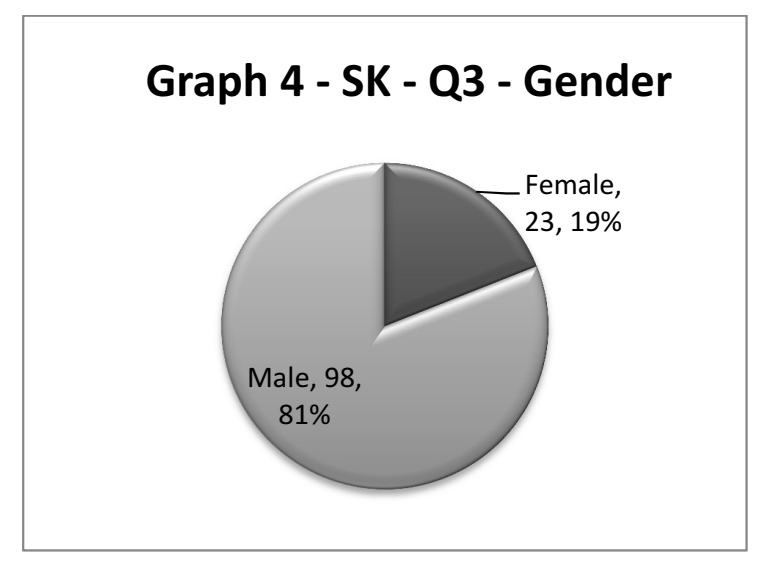

Figure 4. The gender structure of respondents from the Slovakia

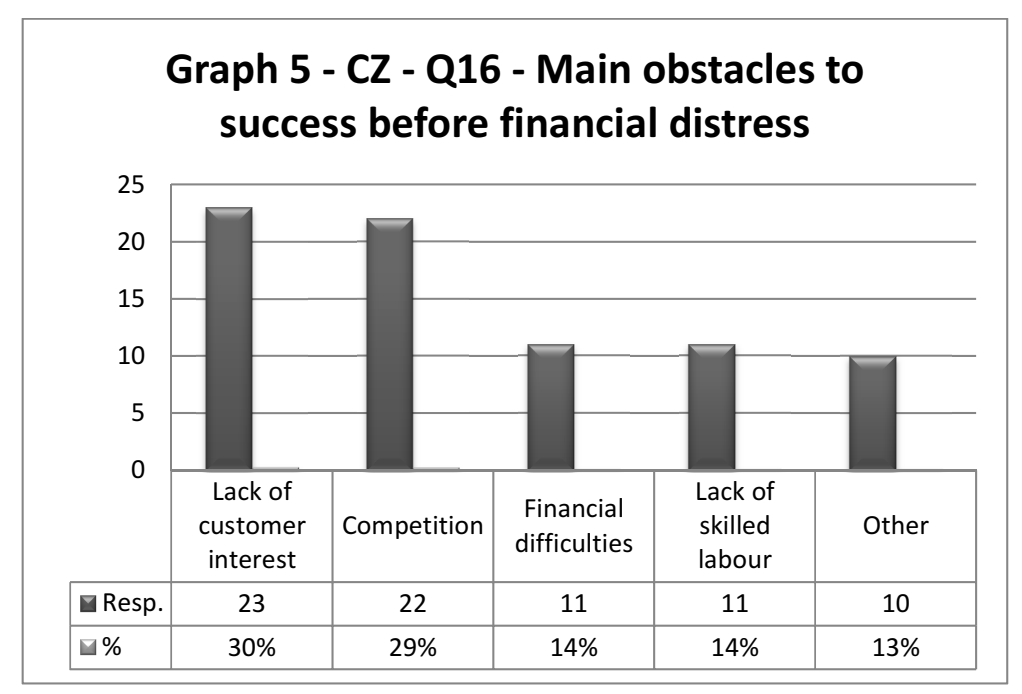

Figure 5. The main obstacles to doing business before the financial crisis- Czech Republic 


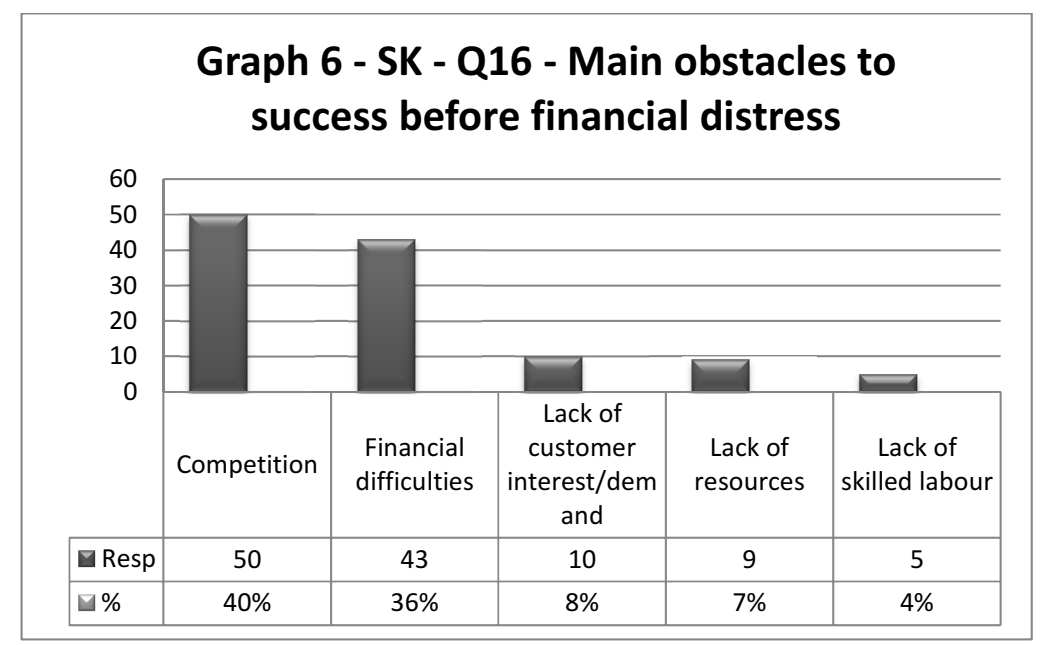

Figure 6. The main obstacles to doing business before the financial crisis- Slovakia

Table 1. Factors important for company's success

\begin{tabular}{lcc}
\hline \multicolumn{1}{c}{ Factors } & Czech Republic & Slovakia \\
\hline Self-Confident & 78 & 105 \\
Need for achievement & 60 & 20 \\
Risk taking & 74 & 9 \\
Creativity & 60 & $\mathrm{X}$ \\
Internal locus of control & 62 & $\mathrm{X}$ \\
Independence & 50 & $\mathrm{X}$ \\
Being educated & 36 & $\mathrm{X}$ \\
\hline
\end{tabular}

\section{Graph - 7 - CZ - Q29 - Age of the company in the time of financial distress}

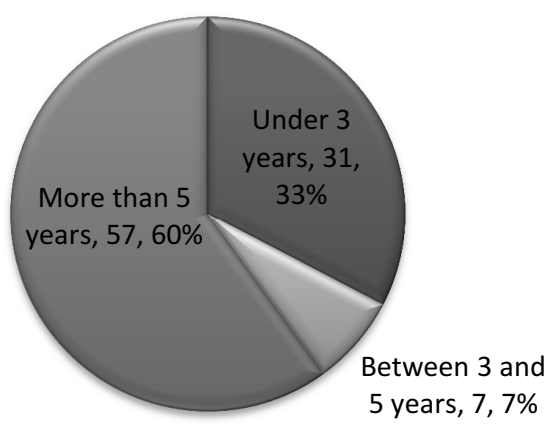

Figure 7. Age of the company in the time of financial distress- Czech Republic 


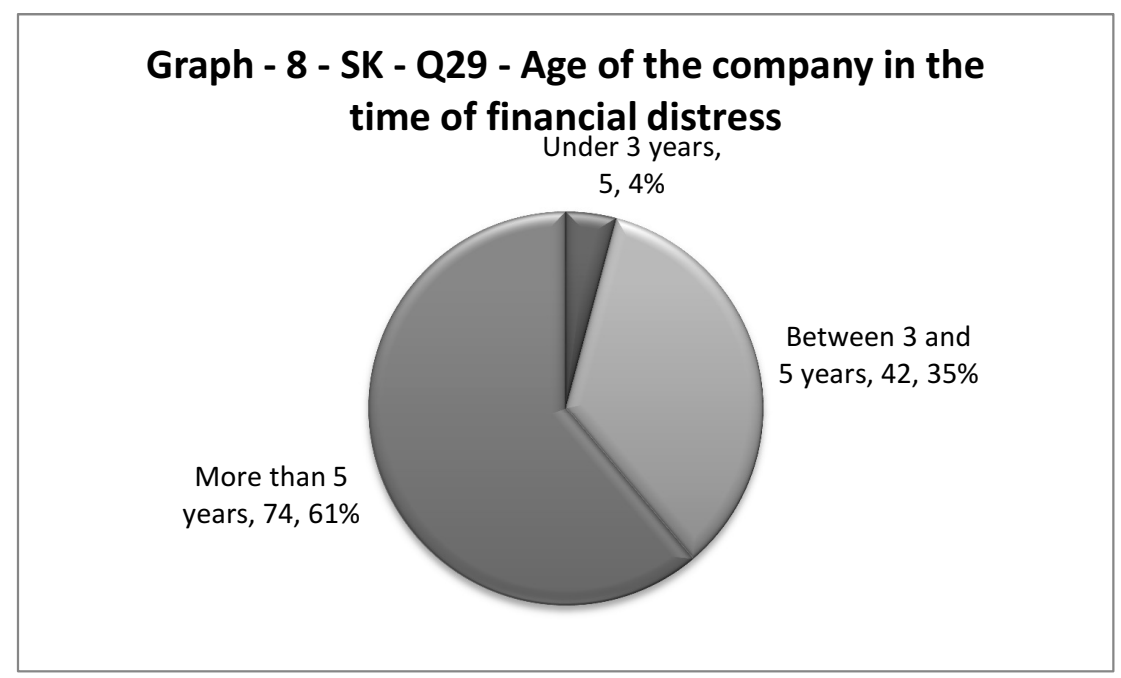

Figure 8. Age of the company in the time of financial distress- Slovakia



Figure 9. Having help in solving your financial problems?- Czech Republic

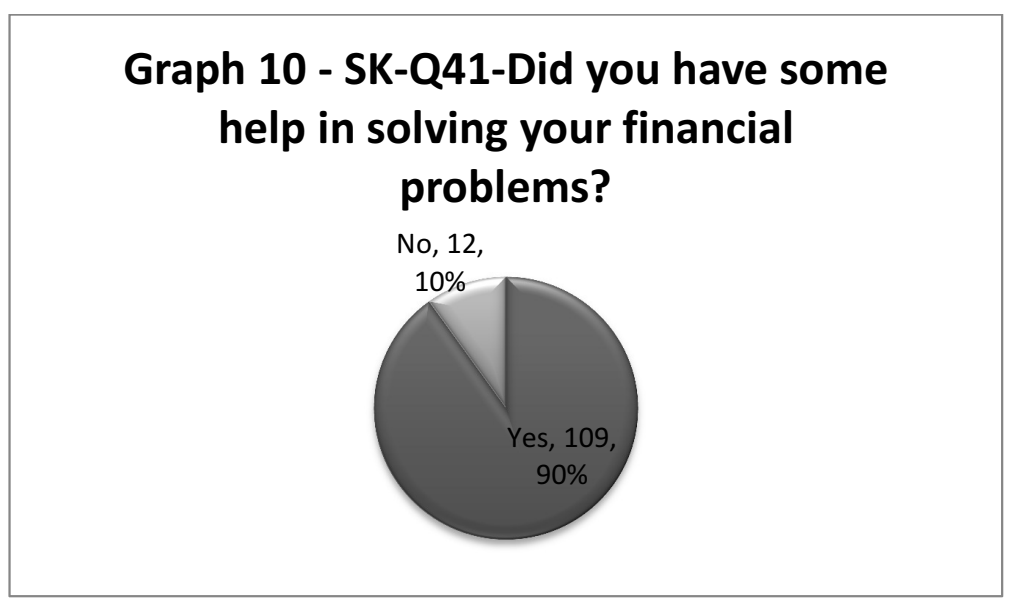

Figure 10. Having help in solving your financial problems?- Slovakia 


\section{DISCUSION}

The main identified obstacles include, in particular, administrative demands and time demands during the founding of the company, an overt administrative burden on small and medium entrepreneurs, instability of the legislative environment, confusedness and opacity of laws, weak enforceability of the law and long-lasting judicial review, a high tax and payment burden and complicated paying of taxes, inadequate length of time for gaining construction permits, insufficient innovation potential and technological readiness of the SME, insufficient access to financing, fragmented context of supporting SME and lingering clientelism and corruption practices. It is recommended that, in order to remove or alleviate the negative impacts of the identified obstacles in the area of SME entrepreneurship, it is especially necessary to simplify and make more effective the process of founding companies, whether with removal of pointless administrative moves (e.g. the necessity of presenting a tax administrator's approval, administrative burden connected to social insurance of employers and self-employed tradesmen), introduction of one universal trade or the fulfilment of the one-stop-shop principle; to ensure the stability of the legislative environment and to improve the enforceability of law and the length of legal proceedings, e.g. through support for the introduction and improvement of informatisation elements in legal proceedings; to stimulate the innovation potential of SME by intensifying cooperation between educational and research institutions and the business community; or to limit the administrative burden of SME and the creation of new burdening regulatory duties, by way of adequate engagement of entrepreneurs into the preparation of new regulations itself.

\subsection{Verification of hypothesis}

H1 Financial difficulties were the main obstacle to success before the final financial crisis.

The first hypothesis has not been confirmed. In the Czech Republic, only 11 respondents (14\%) and in Slovakia 43, which represents $36 \%$, respondents indicated the possibility - financial difficulties - as the main difficulty before the final financial crisis.

H2 The company got into crisis in the first years of business (was not older than 3 years).

The second hypothesis was not confirmed. In the Czech Republic, 31 enterprises $(33 \%)$ got into the crisis, when their business had less than 3 years and in Slovakia only 5 enterprises (4\%).

H3 The most important success factor in business is risk taking.

The third hypothesis was confirmed on a sample from the Czech Republic and refuted on a sample from Slovakia. 74 respondents from the Czech Republic numbered 4 and 5 , on a scale of 1 (least important) to 5 (the most important), with risk taking as the most important success factor in business. In Slovakia only 9 respondents.

\section{CONCLUSION}

The basis of each state is a functional economy, which is made up of several components. One of them is a group of small 
and medium-sized enterprises. An important factor for their survival is the need of greater attention for actions and tools that would prevent negative effects and risks in business activity. The ability of enterprises to maintain a sufficient degree of competitiveness in today's globalized environment requires a consistent management approach and maximum alignment of all organizational activities and actors involved in the performance management process.

In a time of weak economic growth, small and medium enterprises appeared as a driving power of prospering societies. The strengthening of donations for these companies can ensure, that their contributions will broaden, but that requires a renewal of policies focused on the equalisation of conditions for SME in all conditions of the business environment, and especially in the area of financial approach. During the acquiring of financial means, small and medium enterprises still face stricter conditions than large enterprises, it is therefore appropriate to create better conditions and tools allowing for their development.

\section{Acknowledgement}

This paper was supported by the International Visegrad Fund, project number 21820267, titled "How to prevent SMEs failure (Actions based on comparative analysis in Visegrad countries and Serbia)".

\section{References}

2017 SBA Fact Sheet Slovakia. (2019, October 1). European Commission. Retrieved from: ec.europa.eu: https://ec.europa.eu/growth/smes/businessfriendly-environment/performancereview_en\#annual-report

Allah, M.A., \& Nakhaie, H. (2011). Entrepreneurship and risk - taking. Procidings of International Conference on Ebusiness, Management and Economics, 25. IACSIT Press, Singapore. 77-79.

Bartlett, A.C., \& Ghoshal, S. (2003). What is a global manager? Harvard Business Review, 81 (8), 101-108.

Brozyna, J., Mentel, G., \& Pisula, T. (2016). Statistical methods of the bankruptcy prediction in the logistics sector in Poland and Slovakia. Transformations in Business \& Economics, 15 (1), 93-114.

Center for Regional Development of the Czech Republic. (2017). Program for support businesses. Retrieved from: h t t p : / / w w w c cr.cz/c s/podpora podnikani/sluzby-a-poradenstvi/programypodpor-podnikani/.

Czechinvest. (2018). Use of new financial instruments. Retrieved from: https://www.czechinvest.org/cz/Sluzby-promale-a-stredni-podnikatele/Chcetedotace/OPPI/Radce/Definice-maleho-astredniho-podnikatele.

Eliašová, D., Bažó, L., Fodranová, I., Krošláková, M., \& Valenteová, K. (2017). Businesses enterprise (in Slovak). Vydavatel'stvo EKONÓM. Bratislava, Slovakia.

European Commission. (2016). Financial guidelines for applicants. Retrieved from http://www.zcrsr.sk/

European Commission. (2018). Business and SME. Retrieved from: https:/ec.europa.eu/growth/smes_en.

European investment fund. (2016). EaSI Guarantee Instrument. Retrieved from: https://www.eif.org/what_we_do/microfinan ce/easi/easi-guarantee-instrument/index.htm. 


\title{
АНАЛИЗА ПОДРШКЕ И ИДЕНТИФИКАЦИЈА ПРЕПРЕКА ЗА МСП-Е У СЛОВАЧКОЈ И ЧЕШКОЈ
}

\author{
Lenka Labudová, Denisa Jánošová
}

\section{Извод}

Циљ рада је идентификовати главне препреке у малим и средњим предузећима и проценити сличне и различите карактеристике државне подршке предузетништву у Словачкој и Чешкој, на основу детаљне анализе и података из упитника. Рад је подељен у 5 поглавља. У уводу аутори покушавају да се фокусирају на сврху, зашто је важно подржати мала и средња предузећа. Друго поглавље дефинише подршку предузетништву и индивидуалне програме подршке за мала и средња предузећа у Чешкој и Словачкој од стране Европске уније и самих земаља. Треће поглавље фокусира се на одабрана питања истраживања која су рађена под покровитељством пројекта „Како спречити пропадање МСП“. Након тога следи расправа и закључак у којем се истичу највеће препреке за мала и средња предузећа, која их спречавају да успешно остану на тржишту.

Кључне речи: предузетништво, мала и средња предузећа, алати и програми подршке за МСП-е, препреке за МСП-е

European Social Fund in the Czech Republic. (2018). Retrieved from: https://www.esfcr.cz/detail-clanku//asset publisher/BBFAoaudKGfE/content/e vropsky-socialni-fond-v-cr.

Fi Compass. (2019, September). European regional development fund. Retrieved from: https://www.ficompass.eu/esif/erdf

Hanová, S. (2017). Business contribution in 2017. Retrieved from Podnikam.sk: https://podnikam.sk/prispevok-napodnikanie-v-roku-2017/.

Irimia-Dieguez, A., Blanco-Oliver, A., \& Vazquez-Cueto, M. (2015). A Comparison of Classification/Regression Trees and Logistic Regression in Failure Models. Procedia Economics and Finance, 26, 23-28.

Ježková, R. \& Ježek, J. (2011). Entrepreneurship and its municipal and regional support (in Slovak). Eurokódex. Bratislava, Slovakia.

Karas, M., \& Reznakova, M. (2017).
Predicting the Bankruptcy of Construction Companies: A CART-Based Model. Engineering Economics, 28 (2), 145-154.

Kliestik, T., Siekelova, A., \& Misankova, M. (2017). Financial Health Prediction of Company's Business Partners Based on Selected Quantitative and Qualitative Indicators. Journal of Economics, Business and Management, 5 (3), 143-147.

Kliestikova, J., Misankova, M., \& Kliestik, T. (2017). Bankruptcy in Slovakia: International comparison of the creditor' $\mathrm{s}$ position. Oeconomia Copernicana, 8 (2), 221-237.

Liu, J., \& Wu, C. (2017). A gradientboosting decision-tree approach for firm failure prediction: An empirical model evaluation of Chinese listed companies. The Journal of Risk Model Validation, 11 (2), 4364.

Moore, S.E., Ulbrich, H., \& Hepburn, K. (2018). Behavioral economics: a new lens for understanding genomic decision making. 
Journal of Nursing Scholarship, 50 (3), 241248.

Pastuh, D. (2015). Book review: Global Themes and Local Variations in Organization and ManagementPerspectives on Glocalization, Drori, G.S., Höllerer, M.A., Walgenbach P. (Eds.), Routledge, New York/London (2014). Journal of International Management, 21 (1), 78-81.

SARIO. (2018). Support of internationalization of SMEs. Retrieved from The Slovak Investment and Trade Development Agency: https://www.sario.sk/en/support-internationalization-smes.

Slovak Business Agency. (2017a). Guide to initiatives to support SMEs. Retrieved from: http://www.sbagency.sk/podpora-mspv-sr-sprievodca-iniciativami.

Slovak Business Agency. (2017b). Establishment and demise of small and medium enterprises in Slovakia 2017. Retrieved from: https://www.npc.sk/media/uploads/files/Vzn ik_a_zanik_MSP_2017.pdf

Visegrad Fund Project 2018. (2019). How to prevent SMEs from failure (Actions based on comparative analysis in Visegrad countries and Serbia). Reteived from: http://mksm.sjm06.com/. 